\title{
Excess ammonium causes toxicity in watermelon and cucumber plants grown in nutrient solution
}

\section{Excesso de amônio causa toxicidade em plantas de melancia e pepino cultivadas em solução nutritiva}

\author{
Josenyl César França da SILVA FILHO'; José Airton Blamires BATALHA'; Rebecca Karolline Assunção LIMA²; \\ Rafael Silva MELO3; Sâmia dos Santos MATOS ${ }^{4}$; Nilzamara Mendonça do NASCIMENTO ${ }^{5}$; Alexson Filgueiras \\ DUTRA $^{6}$; Gabriel Barbosa da SILVA JÚNIOR ${ }^{7}$ \\ ${ }^{1}$ Eng. Agrônomo, Centro de Ciências Agrárias, Universidade Federal do Piauí, CCA/UFPI, e-mail: josenylcesar@hotmail.com; \\ blamiresairton@gmail.com; \\ 2 Eng. Agrônoma, Mestre em Ciências, Programa de Pós-graduação em Agronomia, Agricultura Tropical, CCA/UFPI, e-mail: \\ rbekstark@gmail.com; \\ ${ }^{3}$ Graduando em Engenharia Agronômica, Departamento de Fitotecnia, Centro de Ciências Agrárias, Universidade Federal do \\ Piauí, CCA/UFPI, e-mail: rafa-sime@hotmail.com; \\ ${ }^{4}$ Eng. Agrônoma, Mestranda em Ciências, Programa de Pós-graduação em Agronomia, Agricultura Tropical, CCA/UFPI, e-mail: \\ samiamatos2011@hotmail.com; \\ ${ }^{5}$ Autor para correspondência, Graduanda em Engenharia Agronômica, Departamento de Fitotecnia, Centro de Ciências \\ Agrárias, Universidade Federal do Piauí, CCA/UFPI, CEP: 64049-550 - Teresina - PI, e-mail: nilzamara.ufpi@gmail.com; \\ ${ }^{6}$ Pesquisador DCR/CNPq/FAPEPI, Departamento de Fitotecnia, Centro de Ciências Agrárias, Universidade Federal do Piauí, \\ Teresina, PI, 60049-550, Brasil, e-mail: alexsondutra@gmail.com; \\ ${ }^{7}$ Professor Adjunto II, Departamento de Fitotecnia, Centro de Ciências Agrárias, Universidade Federal do Piauí, CCA/UFPI, e- \\ mail: gabrielbarbosa@ufpi.edu.br
}

Recebido em: 26-05-2021; Aceito em: 30-06-2021

\begin{abstract}
Excess nitrogen $(\mathrm{N})$ in the form of ammonium $\left(\mathrm{NH}_{4}+\right)$ in the culture medium can induce ammonium toxicity, causing physiological disturbances in plants and resulting in impaired growth and dry matter production. Thus, the aim of this study is to evaluate the growth and dry matter production of watermelon and cucumber plants grown under different nitrogen concentrations in the ammoniacal form and in nutrient solution. The experiment was carried out at the Department of Plant Science located at the Center for Agricultural Sciences, Federal University of Piauí, during the period from October to November 2017. Two cucurbit species, watermelon and cucumber, were studied separately for each experiment using a completely randomized design, with four replicates and five treatments, corresponding to the following ammonium concentrations: $0.5 ; 2.2 ; 4.5 ; 8.7$; and $14.0 \mathrm{mmol} \mathrm{L}^{-1} \mathrm{NH}_{4}{ }^{+}$. Twenty-one days after transplanting the watermelon and cucumber seedlings, the following variables were analyzed: leaf area, leaf chlorophyll index, plant height, stem diameter, root volume, root length, root dry matter, and shoot dry matter. Excess ammonium in the nutrient solution causes toxicity in watermelon and cucumber plants, decreasing plant growth and dry matter production. Symptoms of ammonium toxicity are more evident in the cucumber plant, which presented chlorosis and necrosis followed by plant death after 15 days of cultivation.
\end{abstract}

Additional keywords: ammonia toxicity; Citrullus lanatus; Cucumis sativus; symptomatology.

\section{Resumo}

O excesso de nitrogênio $(\mathrm{N})$ na forma de amônio $\left(\mathrm{NH}_{4}^{+}\right)$no meio de cultivo pode induzir a toxicidade amoniacal, causando distúrbios fisiológicos nas plantas, resultando em prejuízos no crescimento e na produção de matéria seca. Neste sentido, objetivou-se avaliar o crescimento e a produção de matéria seca de plantas de melancia e pepino sob concentrações de nitrogênio na forma amoniacal, em solução nutritiva. O experimento foi desenvolvido no Departamento de Fitotecnia localizado no Centro de Ciências Agrárias da Universidade Federal do Piauí, durante o período outubro a novembro de 2017. Estudou-se separadamente, duas espécies de cucurbitáceas, melancieira e pepineiro, e para cada experimento, utilizou-se o delineamento inteiramente casualizado, com quatro repetições e cinco tratamentos correspondendo às concentrações de amônio $(0,5 ; 2,2 ; 4,5 ; 8,7$ e 14,0 mmol L-1 de $\left.\mathrm{NH}_{4}{ }^{+}\right)$. Aos 21 dias após o transplantio das mudas de melancieira e pepineiro, foram analisadas as seguintes variáveis: área foliar, índice de clorofila foliar, altura de plantas, diâmetro do caule, volume de raiz, comprimento de raiz, massa seca das raízes e da parte aérea. $O$ excesso de amônio em solução nutritiva causa toxicidade em melancieira e em pepineiro, diminuindo o crescimento e a produção de matéria seca de plantas. Os sintomas de toxicidade amoniacal são mais evidentes em pepineiro, que apresentaram clorose e necrose, seguido de morte das plantas aos 15 dias de cultivo.

Palavras-chave adicionais: Citrulus lanatus; Cucumis sativus; sintomatologia; toxicidade amoniacal. 


\section{Introduction}

The production of fruit trees on inert substrates with the use of a nutrient solution emerges as an alternative to conventional systems, being focused on the management of nutritional concentrations and reflecting on plants with better phytochemical and nutritional qualities, with emphasis on the initial growth phase (Silva Júnior et al., 2020).

Scientific investigations that recommend nitrogen fertilization in protected cultures are generalized and only mention the recommendation tables of total $\mathrm{N}$ concentrations in nutrient solutions. In general, studies only refer to nitrate $\left(\mathrm{NO}_{3}{ }^{-}\right)$ concentrations, not including the ammoniacal form $\left(\mathrm{NH}_{4}{ }^{+}\right)$for the cultivation of cucurbits and not addressing their ideal or toxic concentrations for plants (Ma et al., 2019).

Plants have differences in their preferences when absorbing nitrogen to be metabolized and assimilated, with the most predominant forms being $\mathrm{NH}_{4}{ }^{+}$and $\mathrm{NO}_{3}{ }^{-}$. Some plant species are considered tolerant and others sensitive to high concentrations of $\mathrm{NH}_{4}{ }^{+}$(Campos et al., 2020). Excess ammonium can induce toxicity, causing physiological disturbances in plants and impairing physiological and nutritional parameters, as reported for plants of yellow passion fruit (Silva Júnior et al., 2019; Silva Júnior et al., 2020), cucumber (Campos et al., 2016), cauliflower (Barreto et al., 2017), tomato (Barreto et al., 2016), and citrus (Moda et al., 2021).

In plants considered sensitive to $\mathrm{NH}_{4}{ }^{+}$, such as cucurbits, the use of ammonium, even at moderate concentrations, can impair development and may lead to plant death due to biochemical, physiological, and nutritional changes (Ma et al., 2019). Thus, researches that study the ideal concentrations of this nitrogen source are increasingly necessary in order to adjust the crop fertilization program of hydroponic or fertigated systems.

It is hypothesized that high ammonium concentrations cause toxicity symptoms in watermelon and cucumber plants, decreasing growth and dry mass production in the initial growth phase. Thus, the aim of this study is to evaluate the growth and dry mass production of watermelon and cucumber plants grown under different ammonium concentrations in nutrient solution using an inert substrate.

\section{Material and methods}

The experiment was carried out at the Center for Agricultural Sciences (CCA), Federal University of Piauí (UFPI), from October to November 2017. The study was carried out using watermelon plants of cV. Crimson Sweet and cucumber plants of cv. Caipira in the initial growth phase.

For each experiment, a completely randomized design with four replicates and five treatments corresponding to the following ammonium concentrations: 0.52 ; $2.20 ; 4.55 ; 8.75$; and $14.00 \mathrm{mmol}$ $\mathrm{L}^{-1} \mathrm{NH}_{4}{ }^{+}$were used. For each species, four plants were cultivated per experimental plot and developed in an inert substrate using a nutrient solution proposed by Hoagland \& Arnon (1950), modified to $N$ in the ammoniacal form using ammonium chloride as the $\mathrm{N}$ source.

Cucumber and watermelon seeds were sown at a depth of approximately $1.0 \mathrm{~cm}$ in 128-cell polyethylene trays filled with vermiculite (3-4 $\mathrm{mm}$ grain size). The trays were moistened daily and when seedlings presented a pair of fully formed leaves, at ten days after sowing, they were definitively transplanted to tube trays with $100 \mathrm{~cm}^{3}$ volume filled with vermiculite (5$6 \mathrm{~mm}$ grain size) and irrigated twice a day.

The application of treatments with nutrient solutions began seven days after transplanting, as shown in Table 1. Ammonium chloride $\left(\mathrm{NH}_{4} \mathrm{Cl}\right)$ was used for the formulation of the $\mathrm{NH}_{4}{ }^{+}$concentrations. The other macronutrients were supplied using $\mathrm{KH}_{2} \mathrm{PO}_{4}$, $\mathrm{MgSO}_{4} .7 \mathrm{H}_{2} \mathrm{O}$, and $\mathrm{CaCl}_{2}$ as sources. The nutrient solutions were maintained at a $\mathrm{pH}$ value of $6.0 \pm 0.1$ using hydrochloric acid and sodium hydroxide. Once the stock solutions were prepared, the working solutions were prepared, stored in $20 \mathrm{~L}$ gallons, and lined with black polypropylene bags in order to reduce luminosity and prevent the formation of algae in the solutions.

Table 1 - Concentrations of $\mathrm{NH}_{4}{ }^{+}$and other nutrients in the nutrient solution used for the cultivation of cucumber and watermelon.

\begin{tabular}{|c|c|c|c|c|}
\hline $\mathrm{NH}_{4}{ }^{+}$concentrations & $\mathrm{KH}_{2} \mathrm{PO}_{4}$ & $\mathrm{MgSO}_{4}$ & $\mathrm{CaCl}_{2}$ & Micronutrients* \\
\hline \multicolumn{5}{|c|}{ 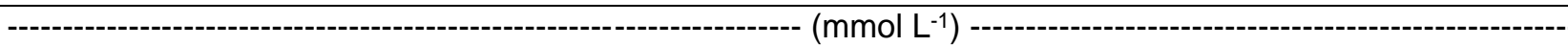 } \\
\hline 0.5 & 1 & 2 & 5 & 1 \\
\hline 2.2 & 1 & 2 & 5 & 1 \\
\hline 4.5 & 1 & 2 & 5 & 1 \\
\hline 8.7 & 1 & 2 & 5 & 1 \\
\hline 14.0 & 1 & 2 & 5 & 1 \\
\hline
\end{tabular}

${ }^{*}$ Micronutrients used $\left(\mathrm{g} \mathrm{L}^{-1}\right): \mathrm{H}_{3} \mathrm{BO}_{3}=2.86 ; \mathrm{MnCl}_{2} .4 \mathrm{H}_{2} \mathrm{O}=1.81 ; \mathrm{ZnCl}_{2}=0.10 ; \mathrm{CuCl}_{2}=0.04 ; \mathrm{H}_{2} \mathrm{MoO}_{4} \mathrm{H}_{2} \mathrm{O}=0.02 ;$ and Fe$\mathrm{EDDH}=40.0$. Source: Adapted from Hoagland \& Arnon (1950). 
For irrigation management, the maximum water retention capacity of the substrate (vermiculite) was determined through gravimetric method, considering the tray mass corresponding to the levels of water retention (LWR) (Machado Neto et al., 2006). The experimental units were weighed daily in order to replace the water lost by evapotranspiration and maintain the levels of water retention in the substrate at $100 \%$. Irrigations were performed daily, once a day, in the late afternoon, and manually using a graduated cylinder.

Twenty-one days after transplanting the watermelon and cucumber seedlings, corresponding to 15 days of application of $\mathrm{N}$ concentrations, when the plants had six or seven fully developed leaves, the following variables were analyzed: leaf chlorophyll index, considering the fourth fully developed leaf and using a portable chlorophyll meter (ClorofiLOG ${ }^{\circledR}$, CFM1030, Falker); stem diameter (mm), measured at two cm from the stem using readings from a digital caliper (Digimess ${ }^{\circledR}, 0.01 \mathrm{~mm}$ ); plant height, measured using a millimeter ruler; leaf area $\left(\mathrm{cm}^{2}\right)$, obtained by the sum of all plants using a digital meter (Li-color Model 3100 Area Meter); root length $(\mathrm{cm})$, measured in the main root using a millimeter ruler; and root volume $(\mathrm{mL})$, measured using a $50 \mathrm{~mL}$ volumetric beaker (Carrigan \& Frey, 1980), with the root volume being considered by the displacement of the water column of the beaker after root immersion.

After these steps, the substrate was removed from the root system using running water. Afterwards, roots and shoots were separated, stored in kraft-type paper bags, and maintained in a forced air circulation oven at a temperature of $65 \stackrel{\circ}{\circ}$ until reaching constant mass, with a duration of approximately 72 hours. After drying, the samples were weighed using a precision scale (accuracy of $0.01 \mathrm{~g}$ ) to determine root and shoot dry mass.

The data were subjected to analysis of variance by the $F$ test $(p<0.05)$ and the polynomial regression models were adjusted according to the coefficient of determination $(\alpha<0.05)$, using the software Assistat 7.7 for analysis (Silva \& Azevedo, 2016). Correlative effects between the variables analyzed in watermelon and cucumber plants were estimated by correlation analysis and heat maps were made using Pearson's correlation coefficients $(p<0.05)$. Analyzes were performed using the software $R$, the 'corrplot' package to generate the heat maps, and the 'rcorr' function to create the coefficient matrices and p-values.

\section{Results and discussion}

Ammonium $\left(\mathrm{NH}_{4}{ }^{+}\right)$concentrations presented a significant effect $(p<0.05)$ on the variables leaf chlorophyll index (LCI), stem diameter (SD), root volume
(RV), root length $(R L)$, and root dry mass (RDM) of watermelon. For cucumber, plant height $(\mathrm{PH})$, root length $(R L)$, root dry mass (RDM), and shoot dry mass (SDM) were significantly influenced $(p<0.01)$ by $\mathrm{NH}_{4}{ }^{+}$ concentrations.

The $\mathrm{LCl}$ of the watermelon plants was fitted to the quadratic regression model as a function of ammonium concentrations. The maximum $\mathrm{LCl}$ (61.2) was found at the estimated concentration of $13.1 \mathrm{mmol}$ $\mathrm{L}^{-1}$ (Figure 1a). The increase in the $\mathrm{NH}_{4}{ }^{+}$concentration in the nutrient solution possibly increased the $\mathrm{N}$ content in the cell cytoplasm. $\mathrm{N}$ participates in a series of compounds that are essential for plant growth and development, with a role in the formation of nitrogenous bases of nucleotides, amino acids, proteins, and chlorophyll molecules (Taiz et al., 2017), justifying the increase in the $\mathrm{LCl}$ as the ammonium concentrations in the nutrient solution increased. However, the effect of the total chlorophyll concentration in the leaf tissue was observed in the present study, considering that there was a decrease in plant dry mass as the concentration of ammonium nitrogen increased due to the toxic effect of this form of nitrogen. The stem diameter of watermelon increased with the application of $\mathrm{NH}_{4}{ }^{+}$up to a concentration of $5.3 \mathrm{mmol} \mathrm{L^{-1 }}$ (Figure 1b). Concentrations above $5.3 \mathrm{mmol} \mathrm{L}^{-1}$ reduced the SD up to $25 \%$. The maximum root volume $\left(1.66 \mathrm{~cm}^{3}\right)$ was obtained with the estimated concentration of $3.7 \mathrm{mmol}$ $\mathrm{L}^{-1} \mathrm{NH}_{4}{ }^{+}$. The $\mathrm{RV}$ was reduced at concentrations above this, with the greatest reduction (51\%) observed when $\mathrm{NH}_{4}{ }^{+}$was supplied at the concentration of $14 \mathrm{mmol} \mathrm{L}^{-1}$ (Figure 1c). There was a reduction in the root length of the watermelon plant (Figure 1d) due to the increase in ammonium concentrations, and the application of 14.0 mmol L-1 $\mathrm{NH}_{4}{ }^{+}$reduced the root length by $35.5 \%$ when compared to the root length of plants cultivated with 0.5 mmol L-1 ammonium.

The plant height (Figure 1e) and root length (Figure 1f) of cucumber decreased as $\mathrm{NH}_{4}+$ increased in the nutrient solution, indicating that $\mathrm{NH}_{4}{ }^{+}$caused severe toxicity to cucumber plants, especially at the highest concentrations of this ion in the culture medium. The highest $\mathrm{NH}_{4}+$ concentration (14.0 mmol L-1) decreased the plant height and root length of cucumber by $50 \%$ and $84 \%$ compared to plants treated with $0.52 \mathrm{mmol} \mathrm{L}^{-1}$ ammonium. The low tolerance of the cucumber plant to excess ammonium may be associated with the site of ammonium assimilation, since its assimilation occurs especially in the plant shoot, where the activity of the enzymes glutamate dehydrogenase (GDH) and glutamine synthetase (GS) is more intense in relation to the activity of these enzymes in the roots (Tian et al., 2021). Studies carried out by Roosta \& Schjoerring (2008) with the same crop showed similar results, indicating that the use of ammonium at concentrations above $5 \mathrm{mmol} \mathrm{L}^{-1}$ caused damage to the growth and development of cucumber plants. 

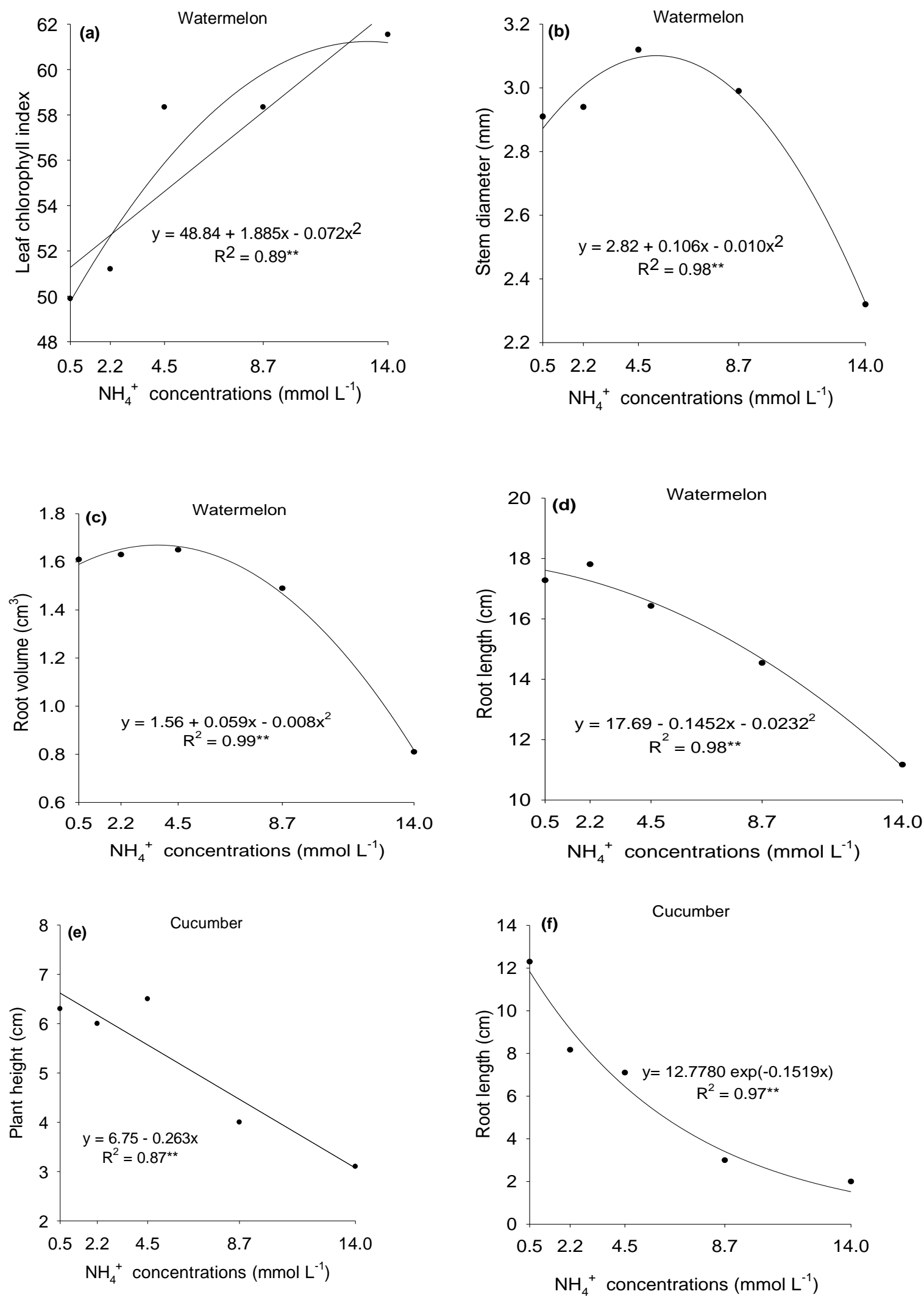

Figure 1 - Leaf chlorophyll index (a), stem diameter (b), root volume (c), and root length (d) of the watermelon plant and plant height (e) and root length (f) of the cucumber plant as a function of $\mathrm{NH}_{4}{ }^{+}$concentrations in nutrient solution. 
The increase in the proportions of ammonium reduced the shoot dry matter (SDM) production of the watermelon plant (Figure 2a). The application of 14.0 mmol $\mathrm{L}^{-1}$ ammonium reduced the SDM by $50 \%$ compared to the supply of $0.5 \mathrm{mmol} \mathrm{L}^{-1}$ in nutrient solution. The shoot (Figure 2c) and root (Figure 2b) dry matter of the cucumber plant were reduced by $49 \%$ and $90.1 \%$, respectively, as the ammonium concentration in the culture medium increased.
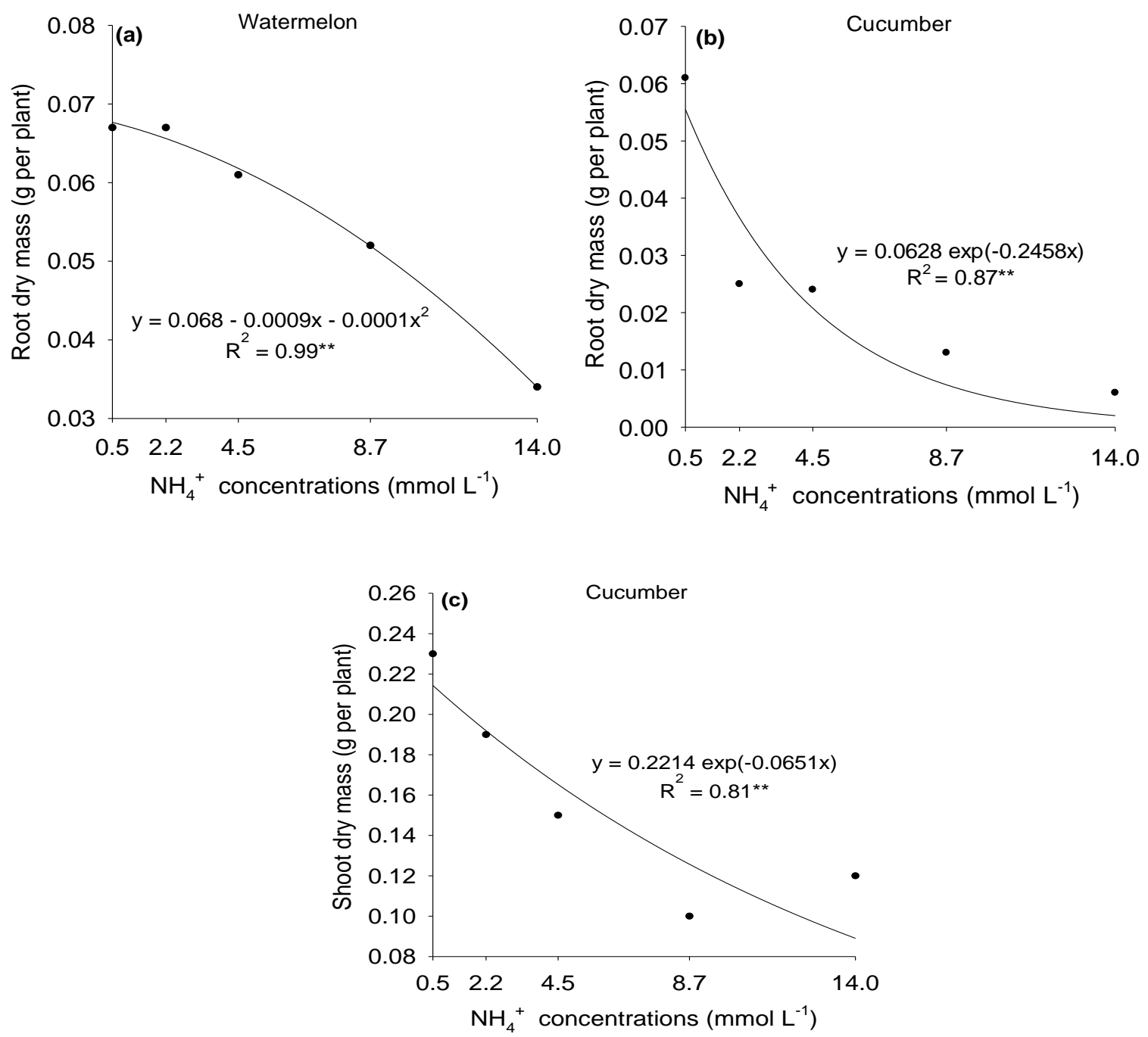

Figure 2 - Root dry mass (a) of the watermelon plant and root (b) and shoot dry mass (c) of the cucumber plant as a function of $\mathrm{NH}_{4}{ }^{+}$concentrations in nutrient solution.

Significant correlative effects were observed between the parameters analyzed in the watermelon plants, except for the correlations between RV and RL, LCI, LA, RDM, and SDM (Figure 3a). LCl presented low correlation with the parameters LA, PH, and SDM, despite presenting significant correlative effect. These results indicate that the excessive absorption of $\mathrm{NH}_{4}+$ by plants results in severe damage to the root system, since it is rapidly affected by $\mathrm{NH}_{4}{ }^{+}$toxicity, decreasing water and nutrient absorption and consequently compromising plant development.

Although presenting significant correlation,
SDM and PH presented low correlation with RL, RDM, $S D$, and RV, which shows the low expressiveness of the shoot/root ratio when analyzed in plants sensitive to ammonium toxicity. On the other hand, strong and positive correlations were found in the correlation between $\mathrm{PH}$ and SDM and LA, as well as in the correlation between SD and RL, RV, and SDM, and between RL and RDM. Correlations between the growth parameters of the cucumber plant were positive and significant (Figure 3b). Only the correlation between SDM and PH and RDM had no significant effect. 


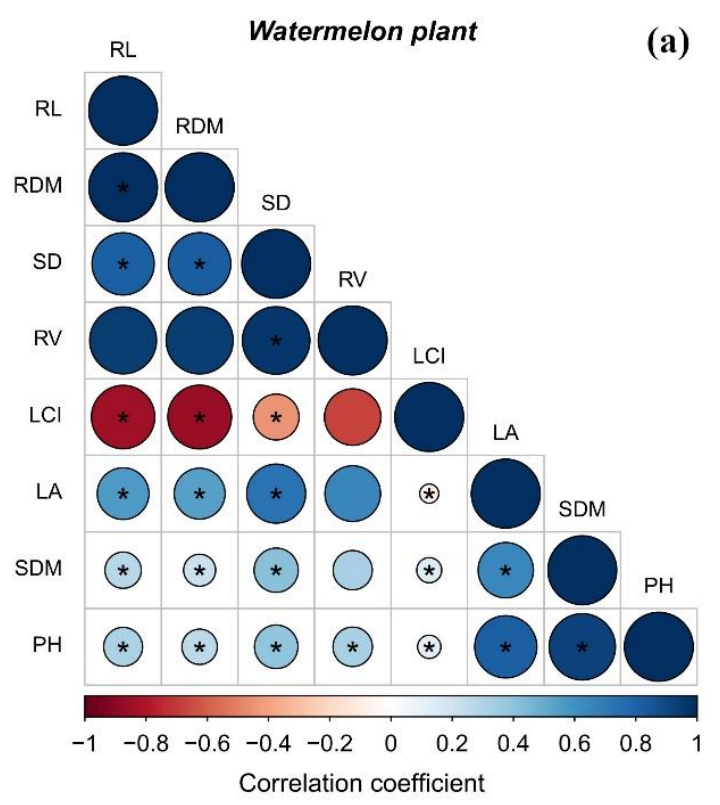

Cucumber plant

(b)

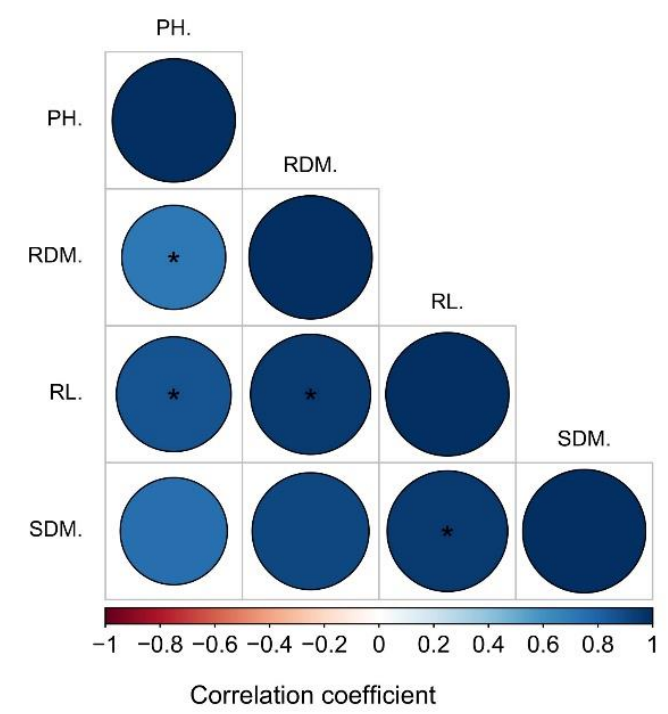

Figure 3 - Heat maps of Pearson's correlations between the parameters analyzed in the watermelon plant (a) and cucumber plant (b). ${ }^{*}$ indicates significant correlation $(p<0.05)$. Abbreviations: chlorophyll index (LCl), plant height (PH), stem diameter (SD), leaf area (LA), root volume (RV), root length (RL), root dry mass (RDM), and shoot dry mass (SDM).

$\mathrm{N}$ absorption in ammoniacal form has the advantage to have the element in its reduced form. However, the flow of ammonium absorption is difficult to control as nitrogen requires cellular homeostasis, which can induce toxicity to plants (Bittsánszky et al., 2015). Thus, most vegetables develop symptoms that demonstrate $\mathrm{NH}_{4}{ }^{+}$toxicity when grown in environments with excess of this nitrogenous form, which may cause older leaves to present senescence, resulting in plant death with the worsening of symptoms (Sousa et al., 2021). In the present study, only the cucumber plants cultivated at concentrations above $8.7 \mathrm{mmol} \mathrm{L}^{-1}$ presented necrosis and death of the plant tissue, which shows the toxicity of $\mathrm{NH}_{4}{ }^{+}$and the sensitivity of this species still in the young stage of the plant and after exposure for a short time to excess $\mathrm{NH}_{4}{ }^{+}$. The lowest dry mass production of cucumber plants grown under conditions of ammonium toxicity was also verified by Roosta \& Schjoerring (2008) and Campos et al. (2016). The relationship between excess $\mathrm{NH}_{4}+$ in the culture medium and lower plant growth was also reported for passion fruit plants (Silva Júnior et al., 2020), citrus (Moda et al., 2021), and rice (Sousa et al., 2021).

Ammonium toxicity causes biochemical and physiological changes in the plant, such as, namely: changes in intracellular $\mathrm{pH}$, osmotic balance, and hormone metabolism (LI et al., 2014); induction of nutrient deficiency (Silva Júnior et al., 2020); and increases in $\mathrm{O}_{2}{ }^{-}$and $\mathrm{H}_{2} \mathrm{O}_{2}$ contents, which can cause oxidative stress, decreasing chlorophyll indexes (Sousa et al., 2021) and photosynthetic rates (Tian et al., 2021), besides affecting dry mass production and possibly resulting in plant death.

The damage caused to the root system of watermelon and cucumber plants by excess $\mathrm{NH}_{4}{ }^{+}$is related to the inhibition of primary root growth by the suppression of the zone of cell elongation (Liu et al. 2013). Thus, excess $\mathrm{NH}_{4}+$ increases the $\mathrm{NH}_{4}{ }^{+}$efflux in the meristematic zone, which is conferred by the action of GDP-mannose pyrophosphorylase (GMPase), an enzyme that presents high sensitivity to $\mathrm{NH}_{4}{ }^{+}$. Thus, growing cells both in the elongation zone and in the meristem are the most sensitive to excess ammonium in the culture medium ( $\mathrm{Li}$ et al., 2014).

For the watermelon crop, moderate growth of watermelon plants is observed when they are subjected to low ammonium concentrations (Figure 4a), especially in the range from 0.5 to $2.2 \mathrm{mmol} \mathrm{L}^{-1}$, indicating good assimilation of $\mathrm{NH}_{4}{ }^{+}$in the ammoniacal form, which is confirmed by the results observed for the phytotechnical variables of this species (Figures 1 and 2). Thus, the symptoms of ammonium toxicity were registered only at the concentration of $14 \mathrm{mmol} \mathrm{L}^{-1}$, presenting reduced plant growth and root necrosis, with roots being darkcolored 15 days after the beginning of the induction of plants to ammonium toxicity. 

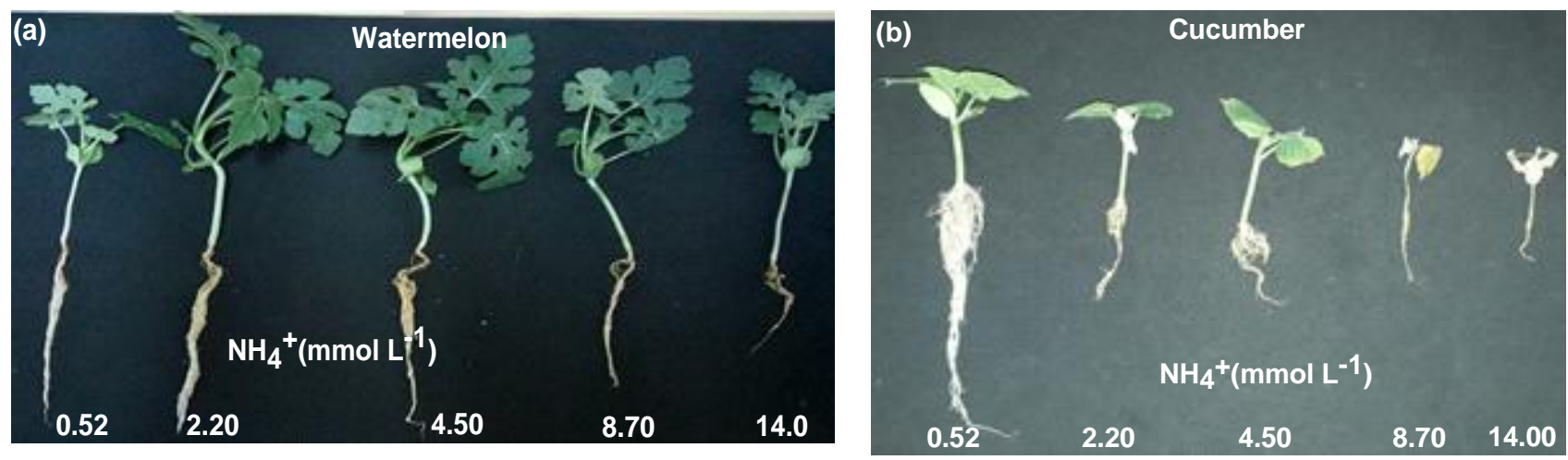

Figure 4 - Images illustrating the root and shoot growth of watermelon (a) and cucumber (b) plants as a function of $\mathrm{NH}_{4}{ }^{+}$concentrations in nutrient solution.

In general, plants may adopt strategies when grown under conditions of high ammonium concentrations, including regulating the $\mathrm{NH}_{4}{ }^{+}$ transporter and increasing the assimilation of this ion, promoting its rapid incorporation into the carbon chain and preventing its accumulation in the cytoplasm (Tian et al., 2021). However, it is known that damage at the subcellular level occurs even before the effect of excess ammonium is externalized, which justifies the plant growth reduction at high ammonium concentrations (14.0 mmol L-1), reflecting in reduced plant growth and dry mass production.

On the other hand, the first symptoms of ammonium toxicity were observed 12 days after the beginning of the application of the ammonium concentrations in cucumber plants in the initial growing phase (Figure $4 \mathrm{~b}$ ), especially from the $4.5 \mathrm{mmol} \mathrm{L}^{-1}$ concentration onwards. Initially, symptoms of chlorosis, followed by necrosis, were observed in old leaves, with a rapid transition of symptoms to young leaves and the leaf apex. Consequently, plants under these conditions presented reduced growth. From $8.7 \mathrm{mmol} \mathrm{L}^{-1}$ of ammonium applied in the nutrient solution onwards, the symptoms of excess ammonium were more intense, causing the death of cucumber plants 15 days after the beginning of treatments, presenting totally necrotic, dark-colored roots. Thus, the results of this study confirm the toxic effect of ammonium in cucurbits, classified as sensitive to excess ammonium (Roosta \& Schjoerring, 2008; Campos et al., 2016).

In the literature, several studies reported the symptoms of ammonium toxicity in plants, which are characterized as chlorosis, necrosis, leaf wilting, senescence, and reduced root and shoot growth. Plant death may occur in cases of severe toxicity (LI et al., 2014; Campos et al., 2016; Silva Júnior et al., 2020; Moda et al., 2021).

Plant responses regarding the absorption of ammoniacal $\mathrm{N}$ are very broad, with reports of differences among families, species or cultivars regarding their development under conditions of excess ammonium (Cruz et al., 2011). In the literature, there are indications of tolerance and sensitivity of some plant species to $\mathrm{NH}_{4}{ }^{+}$according to plant development and as a function of concentrations and time of exposure to ammoniacal $\mathrm{N}$, a situation verified in the present study (Campos et al., 2020).

\section{Conclusions}

Excess ammonium in the nutrient solution causes toxicity to watermelon and cucumber plants, decreasing plant growth and dry matter production. Symptoms of ammonium toxicity are more evident for the cucumber plant, which presented chlorosis and necrosis followed by plant death after 15 days of cultivation.

\section{Acknowledgement}

To the Federal University of Piauí (UFPI) for providing the infrastructure to carry out this research and to the "ad hoc" reviewers for the valuable contributions given through the suggestions and corrections to this article.

\section{References}

Barreto RF, Prado RM, Leal AJF, Troleis MJB, Silva Júnior GB, Monteiro CC, Santos LCN, Carvalho RF (2016) Mitigation of ammonium toxicity by silicon in tomato depends on the ammonium concentration. Acta Agriculturae Scandinavica, Section B - Soil \& Plant Science 66(6):483-488.

Barreto RF, Schiavon Júnior AL, Maggio MA, Prado RM (2017) Silicon alleviates ammonium toxicity in cauliflower and in broccoli. Scientia Horticulturae 225:743-750.

Bittsánszky A, Pilinszk K, Gyulai, Komives T (2015) Overcoming ammonium toxicity. Plant Science 231(4):184-190. 
Campos CNS, Prado RM, Caione G, Neto AJL, Mingotte FLC (2016) Silicon and excess ammonium and nitrate in cucumber plants. African Journal of Agricultural Research 11(4):276-283.

Campos CNS, Silva Júnior GB, Prado RM, David CHO, Souza Júnior JP, Teodoro JP (2020) Silicon mitigates ammonium toxicity in plants. Agronomy Journal 112(2):635-647.

Carrigan L, Frey KJ (1980) Root volumes of Avena species. Crop Science 20(3):407- 408.

Cruz C, Domínguez VMD, Aparicio TPM, Lamsfus CBA, Martins LMA, Moran JF (2011) Intra-specific variation in pea responses to ammonium nutrition leads to different degrees of tolerance. Environmental and Experimental Botany 70(2-3):233-243.

Hoagland DR, Arnon DI (1950) The water culture method for growing plants without soils. 2ed. Agricultural Experimental Station 32p (Circular técnica).

Li B, Li G, Kronzucker HJ, Baluska F, SHI W (2014) Ammonium stress in Arabidopsis: signaling, genetic loci, and physiological targets. Trends in Plant Science 19(2):107-114.

Liu Y, Lai N, Gao K, Chen F, Yuan L, Mi G (2013) Ammonium inhibits primary root growth by reducing the length of meristem and elongation zone and decreasing elemental expansion rate in the root apex in Arabidopsis thaliana. Plos One 8(4):61031.

Ma, Chao, Ban, Tiantian YU, Hongjun, LI, Qiang, Xiaohui, Jiang, Weijie, Xie, Jianming (2019). Urea Addition Promotes the Metabolism and Utilization of Nitrogen in Cucumber. Agronomy 9(5):262.

Machado Neto NB, Custódio CC, Carvalho PR, Yamamoto NL, Cacciolari C (2006) Casca de pinus: avaliação da capacidade de retenção de água e da fitotoxicidade. Colloquium Agrariae 1(1):19-24.

Moda LR, Prado RM, Souza Júnior JP, Silva Júnior GB, Santos LCN, Soares MVG, Kadyampakeni DM (2021) Response of orange seedlings to the proportion of nitrate-ammonium in the nutrient solution and the benefits of phosphorus in ammonia toxicity. Scientia Horticulturae 285:e110166.
Roosta HR, Schjoerring JK (2008) Effects of nitrate and potassium on ammonium toxicity in cucumber plants. Journal of Plant Nutrition 31(7):1270-1283.

Silva FAS, Azevedo CAV (2016) The Assistat Software Version 7.7 and its use in the analysis of experimental data. African Journal of Agricultural Research 11(39):3733-3740.

Silva Júnior GB, Prado RM, Campos CNS. Agostinho FB, Silva SLO, Santos LCN, Castellanos LG (2019) Silicon mitigates ammonium toxicity in yellow passionfruit seedlings. Chilean Journal of Agricultural Research 79(3):425-434.

Silva Júnior GB, Prado RM, Silva SLO, Campos CNS, Castellanos LG, Santos LCN, Barreto RF, Teodoro PE (2020) Nitrogen concentrations and proportions of ammonium and nitrate in the nutrition and growth of yellow passion fruit seedlings. Journal of Plant Nutrition 43(16):2533-2547.

Sousa RT, Paiva ALS, Carvalho FEL, Alencar VTCB, Silveira JMAG (2021) Ammonium overaccumulation in senescent leaves as a novel exclusion mechanism to avoid toxicity in photosynthetically active rice leaves. Environmental and Experimental Botany 186:e104452.

Taiz L, Zeiger E, Moller IM, Murphy A (2017). Fisiologia e desenvolvimento vegetal. Artmed. 838p

Tian X, Fang Y, Jin Y, Yi Z, Li J, Du A, He K, Huang Y, Zhao $H$ (2021) Ammonium detoxification mechanism of ammonium-tolerant duckweed (Landoltia punctata) revealed by carbon and nitrogen metabolism under ammonium stress. Environmental Pollution 277:e116834. 